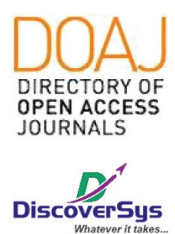

Published by DiscoverSys

\title{
Disregulasi IL-17, CD4 neutrofil, IL-10, PGE-2, iNOS, dan MMP-9 di jaringan kulit terhadap kerusakan saraf dermal pada pasien erythema nodusum leprosum
}

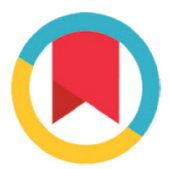

CrossMark

\author{
I Gusti Nyoman Darmaputra ${ }^{1,2^{*}}$, Cita Rosita Sigit Prakoeswa ${ }^{1}$, Anang Endaryanto', \\ I Gusti Agung Ayu Elis Indira ${ }^{2}$, Nyoman Suryawati ${ }^{2}$, Evy Ervianti ${ }^{2}$, Linda Astari ${ }^{2}$, Bagus ${ }^{2}$
}

\section{ABSTRACT}

Introduction: The mechanism of nerve damage in ENL patients is important to be revealed because the problem of nerve damage is not getting enough attention in handling ENL patients. Some proinflammatory mediators that have been studied are risk factors for nerve damage in ENL.

Aim: This study aim in knowing the mechanism of nerve damage in the relation with its risk factors, which are CD64 neutrophil, LL-17, MMP-9, and iNOS with PGE-2 and IL-10 protective factor and IL-10 in ENL patients.

Method: This is an analytic cross-sectional design study with tissue samples from 30 leprosy patients with ENL in Dr. Soetomo General
Hospital Surabaya. Samples from biopsy examined using IHC method to evaluate S-100, IL-10, IL-17, PGE-2, iNOS, MMP-9, and CD64 neutrophil expressions. The result calculated within 20 view field with 1000 times magnification.

Result: CD64 neutrophil $(p=0.022, r=-0.417), I L-17(p=0.001$, $r=-0.560)$, iNOS ( $p=0.005, r=-0.502)$ and MMP-9 $(p=0.025, r=-$ 0.409 ) has significant correlation with $S-100$. There is no significant correlation between IL-10 ( $p=0.061)$ and PGE-2 $(p=0.407)$ with S-100.

Conclusion: Expressions of IL-17, CD64 neutrophil, MMP-9, and iNOS in tissue correlate with nerve damage in ENL patients.
${ }^{1}$ Ilmu Kedokteran Jenjang Profesi Doktor, Fakultas Kedokteran Universitas Airlangga ${ }^{2}$ Bagian/SMF IImu Kesehatan Kulit dan Kelamin, Fakultas Kedokteran Universitas Udayana/Rumah Sakit Umum Pusat Sanglah Denpasar

\section{*Koresppondensi:}

I Gusti Nyoman Darmaputra; IImu Kedokteran Jenjang Profesi Doktor, Fakultas Kedokteran Universitas Airlangga;

Bagian/SMF IImu Kesehatan Kulit dan Kelamin, Fakultas Kedokteran Universitas Udayana/Rumah Sakit Umum Pusat Sanglah Denpasar; darmaputrakulit@yahoo.com

Diterima : 14-03-2019

Disetujui : 28-07-2019

Diterbitkan : 01-08-2019
Keywords: CD64 neutrophil, IL-17, PGE-2, IL-10, MMP-9, iNOS, ENL

Cite This Article: Darmaputra, I.G.N., Prakoeswa, C.R.S., Endaryanto, A., Indira, I.G.A.A.E., Suryawati, N., Ervianti, E., Astari, L., Bagus. 2019. Disregulasi IL-17, CD4 neutrofil, IL-10, PGE-2, iNOS, dan MMP-9 di jaringan kulit terhadap kerusakan saraf dermal pada pasien erythema nodusum leprosum. Intisari Sains Medis 10 (2): 521-526. D01: 10.15562/ism.v10i2.441

\section{ABSTRAK}

Pendahuluan: Mekanisme kerusakan saraf pada pasien ENL penting untuk diungkap karena masalah kerusakan saraf kurang mendapatkan perhatian dalam penanganan pasien ENL. Beberapa mediator proinflamasi yang telah diteliti menjadi faktor resiko terjadinya kerusakan saraf pada ENL.

Tujuan: Tujuan penelitian ini untuk mengetahui hubungan faktor inflamasi seperti IL-17, CD64 neutrofil, MMP-9, dan iNOS serta faktor protektif IL-10 dan PGE-2 terhadap kerusakan saraf pada pasien kusta dengan ENL.

Metode: Penelitian dengan rancangan potong-lintang menggunakan sampel jaringan dari 30 pasien kusta dengan ENL di
RSUP Dr. Soetomo, Surabaya. Biopsi lesi ENL dengan metode IHC untuk mengetahui ekspresi S-100, IL-10, IL-17, PGE-2, iNOS, MMP9, dan CD64 neutrofil. Penghitungan melalui 20 lapang pandang pada pembesaran 1000 kali dengan mikroskop.

Hasil: CD64 neutrofil $(p=0,022 ; r=-0,417)$, IL-17 $(p=0,001$; $r=-0,560)$, iNOS $(p=0,005 ; r=-0,502)$ dan MMP-9 $(p=0,025 ; r=-$ $0,409)$ memiliki hubungan signifikan dengan S-100. Tidak terdapat hubungan antara IL-10 $(p=0,061)$ dan PGE- $2(p=0,407)$ dengan S-100.

Simpulan: Ekspresi IL-17, CD64, iNOS, MMP-9 di jaringan kulit berpengaruh terhadap kerusakan saraf pada ENL. 


\section{PENDAHULUAN}

Reaksi kusta merupakan penyebab utama kerusakan saraf pada kusta, namun sampai saat ini mekanismenya belum diketahui dengan jelas. Terdapat dua jenis reaksi kusta yaitu reaksi kusta tipe 1 dan reaksi kusta tipe 2 atau yang dikenal dengan istilah erythema nodusum leprosum (ENL). ENL umumnya terjadi pada pasien kusta tipe lepromatosa yaitu kusta tipe borderline lepromatous (BL) dan lepromatous lepromatous (LL). ${ }^{1}$ Sebanyak 30-77\% pasien ENL akan berkembang menjadi ENL kronis maupun berulang dan derajat keparahan ENL dapat berubah-ubah saat terjadinya reaksi ENL berikutnya. Kerusakan saraf lebih sering terjadi pada ENL kronis atau berulang dibandingkan ENL akut. Kerusakan saraf umumnya berupa kerusakan saraf dermal yaitu berupa demielinasi yang dapat dideteksi menggunakan pemeriksaan immuno histo chemistry (IHC) dengan pengecatan S-100 untuk mendeteksi struktur schwann cells (SC). ${ }^{1,2}$ Kasus ENL di Asia tergolong tinggi yaitu antara 19-26\% dari keseluruhan kasus BL dan LL. ${ }^{3}$ Berdasarkan data Divisi Kusta Unit Rawat Jalan Ilmu Kesehatan Kulit dan Kelamin RSUD Dr. Soetomo Surabaya periode tahun 2011 - 2013, terdapat 24\% dari seluruh kasus kusta baru mengalami ENL. ${ }^{4}$

Neutrofil merupakan infiltrat sel radang utama pada ENL dimana terjadinya akumulasi neutrofil di jaringan kulit disebabkan oleh adanya peningkatan ekspresi E-selectin pada endotel akibat rangsangan interleukin 17 (IL-17) dan interferon $\gamma$ (IFN- $\gamma)$. Neutrofil yang mengekspresikan cluster of differentiation 64 (CD64) dijumpai meningkat baik di sirkulasi darah maupun di jaringan kulit pada pasien ENL serta terbukti berkaitan dengan derajat keparahan ENL. ${ }^{6}$ Namun pengaruh neutrofil yang aktif terhadap kerusakan saraf pada ENL masih belum diketahui. Neutrofil yang aktif menghasilkan berbagai mediator salah satunya radikal bebas yaitu inducible nitric oxide synthase (iNOS) dan gelatinase yaitu matrix metalloproteinase 9 (MMP-9) yang diduga berperan penting dalam menyebabkan kerusakan saraf pada ENL. iNOS yang produksi oleh sel makrofag terbukti dapat merusak saraf pada granuloma pasien kusta tipe borderline tuberkuloid (BT) melalui pembentukan nitric oxide (NO) dan peroksinitrit. ${ }^{6,7}$ Penelitian Teles pada pasien pure neuritic leprosy (PNL), MMP-9 yang diproduksi dari makrofag terbukti dapat merusak lamina basalis SC yang mempunyai peran sebagai blood-nerve barrier sehingga mediator-mediator imun dapat merusak SC secara langsung. ${ }^{8}$ Prostaglandin-E2 (PGE-2) berperan menginduksi produksi interleukin 10 (IL-10) oleh SC. IL-10 dan PGE-2 berperan dalam menekan inflamasi pada saraf. ${ }^{9}$

Mekanisme kerusakan saraf pada ENL dalam kaitannya dengan disregulasi IL-17 dan CD64 neutrofil serta mediator yang dihasilkannya yaitu iNOS dan MMP-9 sebagai faktor risiko serta disregulasi IL-10 dan PGE-2 yang dihasilkan oleh LD sebagai faktor protektif terhadap saraf pasien kusta lepromatosa masih belum diketahui. Penelitian ini bertujuan menganalisis pengaruh disregulasi IL-17 di sirkulasi darah dan jaringan kulit, CD64 neutrofil di sirkulasi darah dan jaringan kulit serta mediator yang dihasilkannya yaitu iNOS dan MMP-9 di jaringan kulit, serta pengaruh IL10 di sirkulasi darah dan jaringan kulit, PGE-2 di jaringan kulit terhadap terjadinya kerusakan saraf pada ENL, sehingga diharapkan dapat dilakukan deteksi dini dan pengembangan terapi untuk penanganan kerusakan saraf pada ENL yang lebih baik.

\section{METODE}

Penelitian ini merupakan suatu studi observasional analitik rancangan potong-lintang. Sebagai kelompok yang diteliti adalah pasien kusta tipe MB yang mengalami reaksi kusta ENL yang datang berobat di Instalasi Rawat Jalan Kesehatan Kulit dan Kelamin RSUD Dr Soetomo selama bulan Juli 2017-September 2017. Sampel dikelompokkan berdasarkan penggolongan derajat keparahan ENL. Sampel penelitian yang dipergunakan adalah pasien kusta tipe MB yang mengalami reaksi kusta ENL yang memenuhi kriteria penerimaan sampel yaitu pasien kusta tipe MB dengan ENL yang ditetapkan secara klinis dan bakteriologis, usia pasien antara 18 sampai 60 tahun, bersedia ikut dalam penelitian ini, yang dinyatakan dengan menandatangani informed consent setelah diberi penjelasan tentang prosedur penelitian. Pasien hamil atau keadaan umum buruk, riwayat trauma/lesi saraf perifer, riwayat terapi thalidomide oral selama 2 hari terakhir dieksklusi dari penelitian ini. Sampel jaringan kulit diambil dengan biopsi plong pada kulit dorsum pedis pasien kusta tipe $\mathrm{MB}$ dengan reaksi ENL kemudian diperiksa dengan metode immuno histo chemistry (IHC) untuk melihat ekspresi IL-17, CD 64 neutrofil, MMP-9, iNOS, PGE-2, IL-10, dan S-100. Dilakukan penghitungan pada 20 area lapangan pandang dengan pembesaran $1000 \mathrm{kali}$, mikroskop Nikon E100 dengan hasil data berskala ratio. Analisis univariat/deskriptif bertujuan menggambarkan karakteristik subjek dan variabel penelitian. Hasil analisis deskriptif ditampilkan dalam Tabel distribusi tunggal. Analisis regresi linier untuk mengetahui pengaruh variabel bebas terhadap variabel tergantung. Keseluruhan analisis data diatas menggunakan bantuan software statistik berupa SPSS for windows versi 22.0. Penelitian ini telah mendapatkan keterangan kelaikan etik 
Tabel 1 Gambaran karakteristik subjek penelitian

\begin{tabular}{lr}
\hline \multicolumn{1}{c}{ Karakteristik } & $\mathbf{n}=\mathbf{3 0}$ sampel \\
\hline Umur & $3(10,0 \%)$ \\
$11-20$ tahun & $8(26,7 \%)$ \\
$21-30$ tahun & $9(30,0 \%)$ \\
$31-40$ tahun & $7(23,3 \%)$ \\
$41-50$ tahun & $3(10,0 \%)$ \\
51-60 tahun & \\
\hline Jenis Kelamin & $6(20,0 \%)$ \\
Laki-laki & $24(80,0 \%)$ \\
Perempuan & \\
\hline Pekerjaan & $3(10,0 \%)$ \\
Ibu rumah tangga & $3(10,0 \%)$ \\
Pelajar/mahasiswa & $2(6,7 \%)$ \\
ASN & $22(73,3 \%)$ \\
Swasta & \\
\hline Tipe kusta & $18(60,0 \%)$ \\
LL & $12(40,0 \%)$ \\
BL & \\
\hline Tipe ENL & $0(0,0 \%)$ \\
Akut & $30(100,0 \%)$ \\
Kronis & \\
\hline Derajat keparahan ENL & $9(30,0 \%)$ \\
Ringan & $18(60,0 \%)$ \\
Sedang & $3(10,0 \%)$ \\
Berat & \\
\hline
\end{tabular}

Tabel 2 Gambaran rerata S-100, CD64, IL-17, IL-10, iNOS, MMP-9, PGE-2

\begin{tabular}{lccc}
\hline Variabel & Rerata $\pm \mathbf{D S}$ & $\mathbf{9 5 \%}$ KI & $\mathbf{p}$ \\
\hline Kerusakan saraf (S-100) & $8,40 \pm 3,729$ & $7,01-9,79$ & $0.191^{\star}$ \\
\hline CD64 neutrofil & $19,10 \pm 5,371$ & $17,09-21,11$ & $0.612^{*}$ \\
\hline IL-17 & $11,47 \pm 5,029$ & $9,59-13,34$ & $0.084^{*}$ \\
\hline IL-10 & $6,73 \pm 3,039$ & $5,60-7,87$ & 0.007 \\
\hline iNOS & $11,00 \pm 3,922$ & $9,54-12,46$ & $0.323^{*}$ \\
\hline MMP-9 & $11,53 \pm 4,216$ & $9,96-13,11$ & $0.084^{*}$ \\
\hline PGE-2 & $5,27 \pm 1,929$ & $4,55-5,99$ & $0.191^{*}$ \\
\hline
\end{tabular}

${ }^{\star}$ Uji normalitas data (nilai p) dengan Shapiro-Wilk, data berdistribusi normal bila $\mathrm{p}>0,05$

Tabel 3. Uji korelasi kerusakan saraf terhadap CD64, IL-17, IL-10, iNOS, MMP-9, PGE-2

\begin{tabular}{llll}
\hline & \multicolumn{1}{c}{ Variabel } & \multicolumn{1}{c}{$\mathbf{~}$} \\
\hline & IL-17 & $0.001^{*}$ & -0.560 \\
\cline { 2 - 4 } & IL-10 & 0.061 & -0.346 \\
\cline { 2 - 4 } & CD64 & $0.022^{*}$ & -0.417 \\
\cline { 2 - 4 }$\dot{0}$ & iNOS & $0.005^{*}$ & -0.502 \\
\cline { 2 - 4 } & MMP-9 & $0.025^{*}$ & -0.409 \\
\cline { 2 - 4 } & PGE-2 & 0.407 & 0.157 \\
\hline
\end{tabular}

$\mathrm{p}=$ nilai signifikan

$\mathrm{r}=$ koefisien korelasi pearson

*signifikan bila $\mathrm{p}<0.05$ oleh Komite Etik Penelitian Kesehatan RSUD Dr. Soetomo Surabaya dengan nomor: 345/Panke. $\mathrm{KKE} / \mathrm{V} / 2017$.

\section{HASIL}

Sebanyak 30 sampel kusta dengan ENL masuk dalam kriteria inklusi penelitian ini. Gambaran umum yang dinilai dari subjek penelitian meliputi umur, jenis kelamin, pekerjaan, tipe kusta, dan derajat keparahan ENL dapat dilihat pada Tabel 1.

Gambaran rerata variabel penelitian meliputi S-100, IL-17, CD64, iNOS, MMP-9, PGE-2, dan IL10 di jaringan kulit beserta sebaran normalitas data dapat dilihat pada Tabel 2.

IL-17, CD64, iNOS, dan MMP-9 di jaringan kulit memiliki pengaruh yang signifikan terhadap kerusakan saraf dengan nilai signifikansi masingmasing 0,$001 ; 0,011 ; 0,005 ; 0,012$. PGE-2 dan IL-10 tidak memiliki pengaruh yang signifikan terhadap kerusakan saraf yang dinilai dengan nilai signifikansi masing-masing sebesar 0,203;0,061 $(\mathrm{p}>0,05)$. Korelasi negatif sedang ditunjukkan pada IL-17, CD64, iNOS, dan MMP-9 terhadap kerusakan saraf.

\section{Hasil Pemeriksaan IHC}

Pemeriksaan IL-17 dengan antibodi monoklonal terhadap anti IL-17 menunjukkan hasil positif dengan adanya bercak coklat pada sitoplasma sel limfosit (Gambar 1A). Deteksi CD64 dengan menggunakan antibodi monoklonal terhadap anti CD64 menunjukkan hasil positif dengan adanya bercak coklat pada sitoplasma sel neutrofil (Gambar 1B). Pemeriksaan jaringan kulit dengan double staining untuk mendeteksi iNOS pada sel CD64 neutrofil dengan antibodi monoklonal terhadap anti iNOS dan anti CD 64 menunjukkan hasil positif dengan adanya bercak coklat serta bercak merah pada sitoplasma sel neutrofil (Gambar 1C). Pemeriksaan double staining untuk mendeteksi MMP-9 pada sel CD64 neutrofil dengan menggunakan antibodi monoklonal terhadap anti MMP-9 dan anti CD 64 menunjukkan hasil positif dengan adanya bercak coklat serta bercak merah pada sitoplasma sel neutrofil (Gambar 1D). Pemeriksaan kerusakan saraf dengan menggunakan marker S-100 menggunakan antibodi monoklonal terhadap anti S-100 menunjukkan hasil positif dengan adanya bercak coklat pada sitoplasma SC (Gambar 1G). Pemeriksaan double staining untuk mendeteksi IL-10 pada SC menggunakan antibodi monoklonal terhadap anti IL-10 dan anti S-100 menunjukkan hasil positif dengan adanya bercak coklat serta bercak merah pada sitoplasma sel neutrofil (Gambar 1E). Pemeriksaan double staining untuk mendeteksi PGE-2 pada SC menggunakan 
antibodi monoklonal terhadap anti PGE-2 dan anti S-100 menunjukkan hasil positif dengan adanya bercak coklat serta bercak merah pada sitoplasma SC (Gambar 1F).
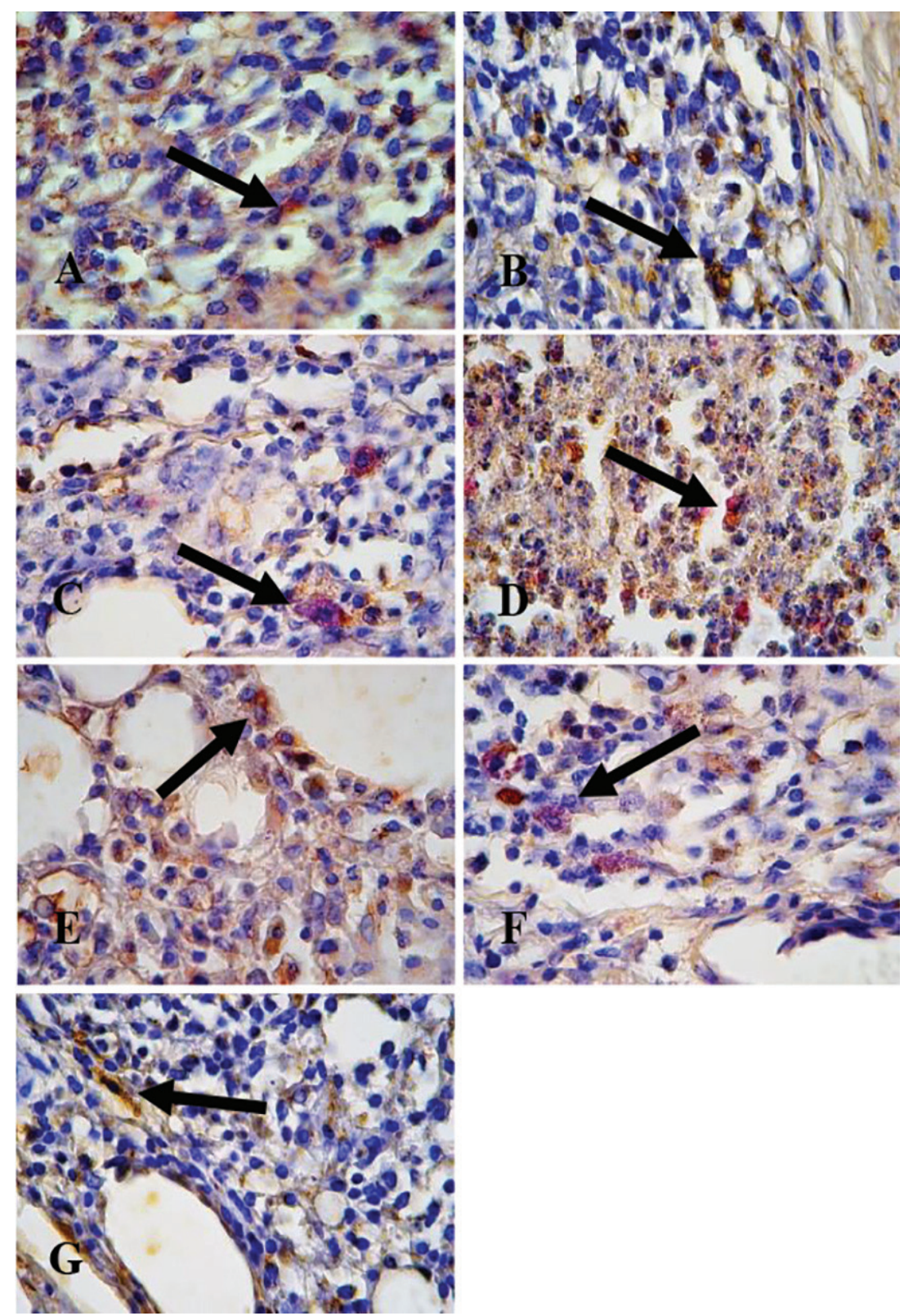

Gambar 1. Sayatan biopsi jaringan kulit dengan pulasan metode IHC menggunakan antibodi monoklonal dan pembesaran 1000 kali. A) Anti human IL-17 (reaksi positif: warna coklat). B) Anti human CD64 (reaksi positif: warna coklat). C) Anti human iNOS dan anti CD 64 (reaksi positif: warna coklat serta merah). D) Anti human MMP-9 dan anti CD 64 (reaksi positif: warna coklat serta merah). E) Anti human IL-10 dan anti S-100 (reaksi positif: warna coklat serta merah). F) Anti human PGE-2 dan anti S-100 (reaksi positif: warna coklat serta merah). G) Anti S-100 (reaksi positif: warna coklat).

\section{PEMBAHASAN}

Kerusakan saraf pada ENL dapat dipengaruhi oleh beberapa mediator di jaringan kulit yang kami kelompokkan sebagai faktor risiko yaitu IL-17 dan CD64 neutrofil serta mediator yang dihasilkannya yaitu iNOS dan MMP-9. IL-17 merupakan sitokin proinflamasi yang terutama dihasilkan oleh sel Th17 pada kondisi inflamasi kronis. IL-17 juga dapat disekresi oleh berbagai macam tipe sel yang berkaitan dengan sistem imunitas alamiah yaitu sel T, sel NK dan neutrofil. ${ }^{10-12}$ Pada penelitian ini IL-17 di jaringan kulit memiliki pengaruh yang signifikan terhadap kerusakan saraf. Ekspresi IL17 di jaringan kulit ditemukan pada demyelinating nerve inflamation serta dijumpai pada Sindrom Guillain-Barré yaitu suatu penyakit demielinasi akut pada saraf perifer. ${ }^{10,13}$ Hasil penelitian ini juga sejalan dengan penelitian Stettner yang meneliti tentang pengaruh IL-17 di jaringan kulit terhadap proses mielinasi dengan menggunakan model co-cultutre dorsal root ganglia pada tikus. IL-17 di jaringan kulit terbukti berperan secara langsung dalam mengganggu fungsi SC dalam proses mielinasi saraf. ${ }^{14}$ Pada penelitian Stettner dijumpai peningkatan aktivitas pro inflamasi dari MMP-9. ${ }^{14}$ Induksi produksi MMP-9 oleh IL-17 juga dijumpai pada penelitian Jovanovic. ${ }^{15}$ Pada penelitian Miljkovic ditemukan bahwa IL-17 juga dapat berperan dalam menginduksi ekspresi iNOS sehingga menimbulkan sitotoksisitas. ${ }^{16}$ IL17 secara tidak langsung berperan menginduksi produksi iNOS dan MMP-9 oleh sel neutrofil sehingga menimbulkan kerusakan SC. IL-17 juga berperan penting dalam menginduksi ekspresi E-selectin pada sel endotel sehingga meningkatkan akumulasi sel neutrofil dan sel radang lainnya di jaringan kulit. ${ }^{14-16}$

Neutrofil merupakan infiltrat dominan pada jaringan kulit pasien ENL. Akumulasi sel neutrofil di jaringan kulit juga disertai pengeluaran toxic oxygen intermediates dan protease yang dapat merusak jaringan kulit sekitarnya, namun peranan neutrofil di jaringan kulit dalam menyebabkan kerusakan saraf dermal masih belum diketahui. ${ }^{12}$ Adanya ekspresi CD64 pada sel neutrofil merupakan pertanda sel neutrofil yang aktif. Peningkatan ekspresi CD64 pada sel neutrofil dipengaruhi oleh IFN- $\gamma$ dan GM-CSF di sirkulasi darah dan jaringan kulit. Pada pasien ENL dijumpai peningkatan IFN- $\gamma$ dan GM-CSF di sirkulasi darah dan jaringan kulit yang sejalan dengan peningkatan ekspresi CD64 di sirkulasi darah dan jaringan kulit. ${ }^{6}$ Penelitian ini merupakan penelitian pertama yang menghubungkan pengaruh neutrofil yang aktif yang ditandai adanya ekspresi CD64 pada neutrofil terhadap kerusakan saraf yang dinilai menggunakan 
S-100. Pada penelitian ini ekspresi CD64 neutrofil di jaringan kulit terbukti memiliki pengaruh yang signifikan terhadap kerusakan saraf yang dinilai dengan S-100 dengan nilai signifikansi $(\mathrm{p}<0,05)$. Penelitian ini sejalan dengan penelitian Schmitz, dijumpai peningkatan ekspresi CD64 neutrofil di jaringan kulit pada pasien ENL. ${ }^{6}$ Penelitian ini juga sejalan dengan penelitian Lee, dimana dijumpai infiltrat neutrofil di jaringan kulit yang terbukti berperan merusak jaringan kulit sekitar. ${ }^{12}$

Peran iNOS produksi neutrofil dalam menimbulkan kerusakan saraf dermal masih belum diketahui. Ekspresi iNOS yang dihitung pada penelitian ini adalah iNOS yang diekspresikan oleh sel neutrofil yang mengekspresikan juga CD64, sehingga spesifik untuk iNOS yang dihasilkan oleh sel neutrofil yang aktif. Pada penelitian ini, iNOS produksi dari neutrofil berpengaruh signifikan terhadap terjadinya kerusakan saraf pada $(\mathrm{p}<0,05)$. Penelitian ini sejalan dengan penelitian Schon, ditemukan banyak makrofag yang mengekspresikan nitrotirosin dan iNOS pada granuloma pasien kusta tipe borderline tuberkuloid (BT) yang menginfiltrasi saraf perifer. Pada proses inflamasi nitric oxide (NO) dapat bereaksi dengan radikal superokside $\left(\mathrm{O}_{2}^{-}\right)$, sehingga menimbulkan peroksinitrit yaitu suatu metabolit yang tidak stabil dan dengan cepat berubah membentuk produk akhir yang lebih stabil yaitu nitrotyrosine (NT). NT dapat menyebabkan peroksidasi lipid dari mielin sehingga menyebabkan terjadinya demielinasi saraf secara langsung. ${ }^{7}$ Pada penelitian ini iNOS produksi sel neutrofil kemungkinan memiliki efek yang sama dalam menimbulkan kerusakan saraf seperti iNOS produksi sel makrofag pada kusta tipe BT. Selain iNOS, sel neutrofil yang aktif juga menghasilkan kolagenase, salah satu kolagenase yang berperan dalam menimbulkan kerusakan saraf adalah MMP9. Peran MMP-9 produksi sel neutrofil dalam merusak saraf dermal pada pasien reaksi kusta ENL belum diketahui. Pada penelitian ini MMP9 terbukti berpengaruh terhadap kerusakan saraf pada pasien ENL $(\mathrm{p}<0,05)$. Cundall membuktikan bahwa protein MMP-9 pada cairan broncho alveolar lavage (BAL) pasien asma berat adalah terutama berasal dari neutrofil dan sisanya berasal dari monosit/makrofag atau sel lain. Terdapat bukti bahwa peningkatan MMP-9 setelah pemberian alergen adalah akibat neutrofil, namun penelitian Cundall masih merupakan penelitian pertama yang menghubungkan MMP-9 produksi sel neutrofil pada cairan BAL dengan derajat keparahan penyakit. ${ }^{17}$ Pada penelitian Teles, membuktikan bahwa MMP9 produksi sel makrofag berperan dalam terjadinya kerusakan saraf dermal pada pasien ENL. MMP-
9 berperan dalam mengontrol sawar darah saraf serta memfasilitasi migrasi sel-sel radang.,8,18 MMP-9 produksi dari sel neutrofil kemungkinan berperan secara tidak langsung merusak SC. MMP-9 berperan merusak kolagen tipe IV yang merupakan komponen penyusun utama lamina basal SC yang berperan sebagai sawar darah-saraf yang melindungi SC dari paparan mediator imun.

Ekspresi IL-10 dan PGE-2 pada SC pasien kusta lepromatosa tanpa adanya reaksi ENL dijumpai meningkat. ${ }^{20}$ PGE-2 dan IL-10 berperan menekan inflamasi pada SC dengan cara menekan produksi NO dan IL-12 oleh SC pada pasien kusta lepromatosa. ${ }^{21}$ Namun belum diketahui ekspresi IL-10 dan PGE-2 pada pasien kusta lepromatosa dengan reaksi ENL. Pada penelitian ini ekspresiPGE-2 di jaringan kulit tidak memiliki pengaruh yang bersifat protektif secara bermakna terhadap kerusakan saraf dermal pada ENL. Hal ini kemungkinan karena pembentukan LD dan PGE-2 pada SC pasien kusta lepromatosa sangat tergantung dengan viabilitas $M$. leprae, dimana sebagian besar pasien mengalami ENL setelah mendapatkan terapi MDT bahkan setelah RFT sehingga jumlah $M$. leprae viable sangat sedikit untuk menginduksi pembentukan lipid droplet dan produknya PGE-2 yang bersifat protektif. Kondisi ini sesuai dengan beberapa penelitian yang menemukan bahwa pada uji klinis yang mengevaluasi pemberian terapi IL10 pada kondisi inflamasi kronis menunjukkan hasil yang tidak sesuai harapan, bahkan pada beberapa kasus kondisi menjadi lebih parah. IL-10 tidak mempengaruhi perjalanan klinis inflamasi kronis. Menariknya, terdapat tren tidak terduga yaitu adanya peningkatan IL-6, IL-8, dan TNF- $\alpha$ setelah pengobatan IL-10. Penelitian oleh Ivashkiv dan kawan-kawan mengenai priming makrofag oleh IFN dan pengaruhnya pada signaling IL-10 sangat penting dalam konteks ini. ${ }^{23}$ Pada penelitian ini tidak dilakukan pemeriksaan ekspresi IFN- $\gamma$ di jaringan kulit, namun pada beberapa penelitian mengenai patogenesis ENL dijumpai peningkatan ekspresi IFN- $\gamma$ pada ENL. ${ }^{22}$ Penelitian ini tidak mengamati secara prospektif pasien kusta tipe $\mathrm{MB}$ dari sebelum ENL sampai kemudian terjadi ENL akut dan menjadi ENL kronis serta sampai terjadi kerusakan saraf, karena tidak dapat diprediksi berapa lama untuk terjadinya ENL sehingga membutuhkan waktu yang sangat lama.

\section{SIMPULAN}

Ekspresi IL-17, CD64, iNOS, MMP-9 di jaringan kulit berpengaruh terhadap kerusakan saraf pada ENL. 


\section{DAFTAR PUSTAKA}

1. Lockwood DN, Saunderson PR. Nerve damage in leprosy: a continuing challenge to scientists, clinicians and service providers. Int Health. 2012;4(2):77-85.

2. Singh N, Arora VK, Ramam M, Tickoo SK, Bhatia A. An evaluation of the S-100 stain in the histological diagnosis of tuberculoid leprosy and other granulomatous dermatoses. Int J Lepr Other Mycobact Dis. 1994;62(2):263-7.

3. Kahawita IP, Walker SL, Lockwood DNJ. Leprosy type 1 reactions and erythema nodosum leprosum. An Bras Dermatol. 2008;83(1):75-82.

4. Novianto A, Listiawan MY. Penderita Kusta dengan Reaksi di Divisi Kusta URJ Penyakit Kulit dan Kelamin RSU Dr Soetomo Surabaya Periode 2004 - 2006. 2007; Belum dipublikasikan.

5. Darmaputra IGN, Herwanto N, Rusyati LM, Riawan W, Endaryanto A, Prakoeswa CRS. Distribution of iNOS expressions and TNF neutrophil cells as well as PGE2 and S100 Schwann cell dermal nerves in the erythema nodosum leprosum patients. Bali Med J. 2018;7(1):262-266.

6. Schmitz V, Prata RB, Barbosa MG, Mendes MA, Brandao SS, Amadeu TP, dkk. Expression of CD64 on circulating neutrophils favoring systemic inflammatory status in Erythema Nodosum Leprosum. PLoS Negl Trop Dis. 2016;10(8):e0004955.

7. Schön T, Hernández-Pando R, Baquera-Heredia J, Negesse Y, Becerril-Villanueva LE, Eon-Contreras JC, dkk. Nitrotyrosine localization to dermal nerves in borderline leprosy. Br J Dermatol. 2004;150(3):570-4.

8. Teles RM, Antunes SL, Jardim MR, Oliveira AL, Nery JA, Sales AM, dkk. Expression of metalloproteinases (MMP2, MMP-9, and TACE) and TNF-alpha in the nerves of leprosy patients. J Peripher Nerv Syst. 2007;12(3):195-204.

9. Mattos KA, D'Avila H, Rodrigues LS, Oliveira LS, Sarno EN, Atella GC, dkk. Lipid droplet formation in leprosy: Tolllike receptor-regulated organelles involved in eicosanoid formation and Mycobacterium leprae pathogenesis. J. Leukoc Biol. 2010;87(3):371-84.

10. Borregaard N, Sørensen OE, Theilgaard-Monch K. Neutrophil granules: a library of innate immunity proteins. Trends Immunol. 2007;28(8):340-5.

11. Griffin GK, Newton G, Tarrio ML, Bu DX, MagantoGarcia E, Azcutia V, dkk. IL-17 and TNF- $\alpha$ sustain neutrophil recruitment during inflammation through synergistic effects on endothelial activation. J Immunol. 2012;188(12):6287-99.

12. Lee DJ, Li H, Ochoa MT, Tanaka M, Carbone RJ, Damoiseaux R, dkk. Integrated pathways for neutrophil recruitment and inflammation in leprosy. J Infect Dis. 2010;201(4):558-69.
13. Li S, Yu M, Li H, Zhang H, Jiang Y. IL-17 and IL-22 in cerebrospinal fluid and plasma are elevated in GuillainBarre syndrome. Mediators of Inflammation. 2012;2012:17.

14. Stettner M, Lohmann B, Wolffram K, Weinberger JP, Dehmel T, Hartung HP, dkk. Interleukin-17 impedes Schwann cell-mediated myelination. J Neuroinflammation. 2014;11:63.

15. Jovanovic DV, Martel-Pelletier J, Di Battista JA, Mineau F, Jolicoeur FC, Benderdour M, dkk. Stimulation of 92kd gelatinase (matrix metalloproteinase 9) production by interleukin-17 in human monocyte/macrophages: a possible role in rheumatoid arthritis. Arthritis Rheum. 2000;43(5):1134-44.

16. Miljkovic D, Trajkovic V. Inducible nitric oxide synthase activation by interleukin-17. Cytokine Growth Factor Rev. 2004;15(1):21-32.

17. Cundall M, Sun Y, Miranda C, Trudeau JB, Barnes S, Wenzel SE. Neutrophil-derived matrix metalloproteinase-9 is increased in severe asthma and poorly inhibited by glucocorticoids. J Allergy Clin Immunol. 2003;112(6):106471.

18. Pandhi D, Chhabra N. New insights in the pathogenesis of type 1 and type 2 lepra reaction. Indian J Dermatol Venereol Leprol. 2013;79:739-49.

19. Friedland JS, Shaw TC, Price NM, Dayer JM. Differential regulation of MMP-1/9 and TIMP-1 secretion in human monocytic cells in response to Mycobacterium tuberculosis. Matrix Biol. 2002;21(1):103-10.

20. Mattos KA, Oliveira VG, D'avilla H, Rodrigues LS, Pinheiro RO, Sarno EN, dkk. TLR6-driven lipid droplets in Mycobacterium leprae-infected Schwann cells: immunoinflammatory platforms associated with bacterial persistence. J Immunol. 2011;187(5):2548-58.

21. Mattos KA, Sarno EN, Pessolani MC, Bozza PT. Deciphering the contribution of lipid droplets in leprosy: multifunctional organelles with roles in Mycobacterium leprae pathogenesis. Mem Inst Oswaldo Cruz, 107 Suppl. 2012;1:156-66.

22. Kahawita IP, Lockwood DN. Towards understanding the pathology of erythema nodosum leprosum. Trans R Soc Trop Med Hyg. 2008;102(4):329-37.

23. Muhl H. Pro-inflammatory signaling by IL-10 and IL22: bad habit stirred up by interferons?. Front immunol. 2013;4:18.

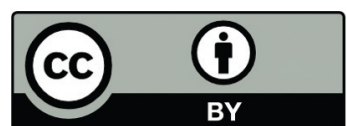

This work is licensed under a Creative Commons Attribution 